\title{
Treatment and Prophylaxis of Catheter-Related Thromboembolic Events in Children
}

\author{
Cortejoso Lucía ${ }^{1}$, Manrique-Rodríguez Silvia ${ }^{1}$, Fernández-Llamazares Cecilia M. ${ }^{1}$, Sanjurjo-Sáez María \\ ${ }^{1}$ Pharmacy Department, Hospital General Universitario Gregorio Marañón, Madrid, Spain
}

Received, June 20, 2012; Accepted, November 27, 2012; Published, November 28, 2012.

\begin{abstract}
Purpose. The therapeutic management of catheter-related thromboembolic events in children is still a challenge due to the large number of potentially effective pharmacological alternatives and the insufficient scientific evidence available. A bibliographic review was performed in order to identify the available pharmacological alternatives for the prophylaxis and therapeutic management of catheter-related thrombosis in children. Methods. A literature search was carried out on MEDLINE using the medical subject heading (MeSH) central venous catheter thrombosis and on Google Scholar. The search was limited to review papers, meta-analyses, clinical practice guidelines, and randomized controlled trials performed on pediatric populations until November 2011. Results. The different options for anticoagulation include unfractionated heparin, low molecular weight heparin and vitamin $\mathrm{K}$ antagonists. Thrombus resolution is stimulated more rapidly with thrombolytic agents than with anticoagulants, but the risk-benefit ratio must be considered. Streptokinase is not considered an optimal alternative due to the risk of anaphylactic reactions and has been replaced by urokinase, alteplase or the newer reteplase. Preventive strategies have been considered and most centers have protocols for routine flushing of the catheter with heparin or normal saline. Intraluminal application of urokinase and alteplase has also been studied. Conclusions. The wide range of options available for the pharmacotherapeutic management of catheter-related thromboembolism in children and the lack of strong evidence on the comparative efficacy and safety of the different therapeutic options, make its positioning rather difficult. Randomized controlled trials and national plans should be set up urgently.
\end{abstract}

This article is open to POST-PUBLICATION REVIEW. Registered readers (see "For Readers") may comment by clicking on ABSTRACT on the issue's contents page.

\section{INTRODUCTION}

Central venous access devices (CVADs) are used in critically ill children and in children with chronic diseases for the administration of fluids, medications, total parenteral nutrition or blood products. The use of CVADs has tremendously improved the quality of care in these children. However, they may also cause several mechanical, infectious and thrombotic complications(1).

Catheter occlusion is defined as a partial or complete obstruction of the catheter that limits or prevents the ability to withdraw blood, flush the catheter, or administer parenteral solutions or medications(2). Thrombotic catheter occlusion accounts for $58 \%$ of all catheter occlusions and occurs when deposits of fibrin or blood within and around CVADs impede or disrupt flow through the catheter(3). It is also postulated that the localized vascular injury inflicted by the catheter induces a local prothrombotic state(4). Peripherally inserted central catheters (PICCs) lines may be more prone to thrombotic occlusion than non-PICC CVADs due to their longer length and smaller diameter(5).
Thrombotic catheter occlusion may delay or even interrupt infusion of therapy and may also contribute to the development of CVAD-related infection as the blood clot serves as a culture medium for bacterial growth(6). Potentially serious complications of deep vein thrombosis include recurrent thrombosis, loss of intravenous access, pulmonary embolism, post-thrombotic syndrome and death(7-12). Although the most commonly recognized complication of CVADs is infection(13-16), diagnosis of thrombotic events related to these devices is becoming increasingly prevalent.

Catheter occlusion can be treated in some cases, avoiding possible complications and cost of catheter replacement(5). Few clinical trials have studied prophylaxis of catheter-related thrombosis in children(17). Thromboembolic events in children are still relatively rare compared to adults and hence uniform recommendations regarding indications,

\footnotetext{
Corresponding Author: Lucía Cortejoso Fernández, Hospital General Universitario Gregorio Marañón, Pharmacy Department, Madrid, Spain. Email Address: lucia.cortejoso@salud.madrid.org
} 
drug of choice, route of administration and dosing regime are not well established(18). Dose regimes have often been extrapolated from adult guidelines, but the fibrinolytic system in children is a dynamic, evolving system with unique features that markedly influence the response to thrombolytic agents(19). In addition, the pathophysiologic mechanisms of thrombosis in children are very different from those in adults.

The presence of a CVAD is the leading cause for thromboembolic complications in children(20). In neonates, systemic infection is the most common risk after the presence of a catheter(21). A variety of inherited predisposing factors to the development of thrombosis have been described including genetic risk factors such as factor V Leiden, prothrombin 20201A, and protein $\mathrm{C}$ and $\mathrm{S}$ deficiencies(4). The reported frequency of catheter thrombosis in children ranges from $5 \%$, including only symptomatic cases, to $50 \%$, when patients are systematically screened for catheter-related thrombosis(1).

Since CVADs are increasingly common in the pediatric population, it is of paramount importance to be aware of new information regarding thromboembolic complications of these devices. The objective of this study is to review the literature in order to identify different pharmacological strategies available for prophylaxis and therapeutic management of catheter-related thrombosis in children, and their positioning in clinical practice. This article focuses on the potential indications, efficacy and safety profiles of different therapeutic options. Concentration, reconstitution/dilution and stability of the main anticoagulant and thrombolytic drugs were also considered. We believe this is the first review that analyzes the quality of the existing evidence and grades of recommendation for each therapeutic option in treatment and prophylaxis of catheter-related thromboembolic events in children.

\section{METHODS}

A search was performed on MEDLINE, through PubMed, using the medical subject heading (MeSH) central venous catheter thrombosis and on Google Scholar. The search was initially limited to meta-analysis, practice guidelines, randomized controlled trials and review papers performed on pediatric populations up to November 2011. Pertinent articles from reference lists of related papers were also taken into consideration as well as non-randomized controlled trials and series of cases when no information of higher-level evidence was available. In addition, summaries of product characteristics for each drug, the Drugdex medicines database from Thomson Micromedex Healthcare Series and Lexi-Comp ONLINE ${ }^{\mathrm{TM}}$ were also reviewed. Quality of the scientific evidence found in literature and associated grades of recommendation were given for each therapeutic option (Table 1).

\section{RESULTS}

\section{Treatment}

The available options for treatment of venous thromboembolism are anticoagulation, thrombolysis and surgery.

\section{Anticoagulation}

The optimal therapy for acute and symptomatic catheter-related thrombosis is prompt removal of the catheter $(1,17)$. If the catheter cannot be removed, anticoagulation should be initiated at full dosage for 3 months followed by prophylaxis until the device is removed $(7,12)$. The aims of initial anticoagulation are to prevent extension of the thrombus and subsequent pulmonary embolism(22).

Table 1. Quality of the scientific evidence and associated grades of recommendation(84)

Classification of evidence levels

Ia: Evidence obtained from meta-analyses of randomized controlled trials

Ib: Evidence obtained from at least one randomized controlled trial

IIa: Evidence obtained from at least one well-designed, non-randomized controlled study

IIb: Evidence obtained from at least one well-designed, "quasi-experimental" study

III: Evidence obtained from well-designed, nonexperimental descriptive studies such as comparative studies, correlation studies, and case reports

IV: Evidence obtained from an expert comitee or expert report and/or from the clinical experience of respected authorities

\section{Categories of recommendation}

A: Based directly on evidence level I

B: Based directly on evidence level II or recommendation extrapolated from level I evidence

C: Based directly in the evidence level III or recommendation extrapolated from level I or II evidence

D: Based directly in the evidence level IV or recommendation extrapolated from level I, II or III evidence 
Unfractionated heparin

Unfractionated heparin (UFH) doses used in the treatment of catheter-related thrombosis are: a loading dose of $75 \mathrm{IU} / \mathrm{kg}$ in 10 minutes intravenously and maintenance doses of 28 $\mathrm{IU} / \mathrm{kg} / \mathrm{h}$ in children less than 1 year old and 20 $\mathrm{IU} / \mathrm{kg} / \mathrm{h}$ in children older than 1 year(12, 22). Evidence level Ib; Category of recommendation B. Commercially available heparins can be diluted with dextrose $5 \%$ or sodium chloride $0.9 \%$. Once diluted, the solution is stable $24 \mathrm{~h}$ at room temperature (Table 3 ).

\section{Low molecular weight heparin}

Low molecular weight heparin (LMWH) therapy administered twice daily subcutaneously has more reliable pharmacokinetics and requires less monitoring in children than warfarin(17). In addition, it is at least as effective as UFH and causes fewer bleeding complications(23). Enoxaparin is the most commonly used LMWH and recommended doses are $1.5 \mathrm{mg} / \mathrm{kg} / 12 \mathrm{~h}$ in children less than 2 months old and 1.0 $\mathrm{mg} / \mathrm{kg} / 12 \mathrm{~h}$ in children older than 2 months with adjustment to achieve anti-factor Xa level of 0.5 to $1 \mathrm{unit} / \mathrm{mL}(12,22)$. Evidence level Ib; Category of recommendation $\mathrm{B}$.

The potential advantages of LMWH for pediatric patients include minimal monitoring requirements, lack of interference from other drugs or diet (compared to vitamin $\mathrm{K}$ antagonists), reduced risk of heparin-induced thrombocytopenia and probable reduced risk of osteoporosis with long term use compared to $\mathrm{UFH}(12)$.

Table 2. Summary of different therapeutic strategies and their evidence level for treatment and prophylaxis of catheter-related thromboembolic events in children

\begin{tabular}{llll}
\hline Objective & Therapeutic options & & Evidence level \\
\hline & & Unfractionated heparin & Ib \\
& Anticoagulation & Low molecular weight heparin & Ib \\
& & Oral anticoagulants & III \\
Treatment & Thrombolysis & Streptokinase & III \\
& & Urokinase & Ib \\
& Surgery & Alteplase & Ib-III \\
& Normal saline flushes & & III \\
& & IV & IV \\
& Anticoagulation & Unfractionated heparin & Ia-Ib \\
& & Low molecular weight heparin & Ib-IIa \\
& & Oral anticoagulants & Ib-III \\
& Thrombolysis & & Ib-IIa \\
\hline
\end{tabular}

Table 3. Concentration, reconstitution/dilution and stability of main anticoagulant and thrombolytic drugs( 37,43 , 85-87)

\begin{tabular}{|c|c|c|c|}
\hline & Concentration & Reconstitution/dilution & Stability \\
\hline $\begin{array}{l}\text { Heparin } \\
\text { sodium }\end{array}$ & $\begin{array}{l}1-200 \mathrm{IU} / \mathrm{mL} \\
\text { depending on } \\
\text { indication }\end{array}$ & $\begin{array}{l}\text { Dilution: dextrose } 5 \% \text { or sodium } \\
\text { chloride } 0.9 \%\end{array}$ & Dilution: $24 \mathrm{~h}$ at room temperature \\
\hline $\begin{array}{l}\text { Urokinase } \\
\text { (UK) }\end{array}$ & $\begin{array}{l}\text { Maximum } \\
\text { concentration not } \\
\text { established }\end{array}$ & $\begin{array}{l}\text { Reconstitution: water for injection } \\
\text { Dilution: sodium chloride } 0.9 \%\end{array}$ & Dilution: $24 \mathrm{~h}$ at room temperature \\
\hline $\begin{array}{l}\text { Alteplase } \\
\text { (rt-PA) }\end{array}$ & $\begin{array}{l}0.2-1 \mathrm{mg} / \mathrm{mL} \\
\text { depending on } \\
\text { indication }\end{array}$ & $\begin{array}{l}\text { Reconstitution: water for injection } \\
\text { Dilution: sodium chloride } 0.9 \%\end{array}$ & $\begin{array}{l}\text { Reconstituted vial: instant use } \\
\text { Dilution: } 24 \mathrm{~h} \text { at room temperature } \\
\text { Freezing solutions: } \\
-0.25 \mathrm{mg} / \mathrm{mL}: 1 \text { year at }-70^{\circ} \mathrm{C} \\
-0.5,1 \text { and } 2 \mathrm{mg} / \mathrm{mL}: 14 \text { days at }-70 \\
\text { and }-25^{\circ} \mathrm{C} \\
\text { Once defrost, no more than } 48 \mathrm{~h} \text { at } 2^{\circ} \mathrm{C}\end{array}$ \\
\hline
\end{tabular}


Oral anticoagulants

Treatment with vitamin $\mathrm{K}$ antagonists can be initiated together with UFH or LMWH. The duration of this initial therapy should be a minimum of 5 days and heparin can be withdrawn when the international normalized ratio (INR) remains stable and $>2(22)$. The choice of antivitamin $\mathrm{K}$ (warfarin, acenocoumarol or phenprocoumon) depends on availability in each country. Safety and efficacy in pediatric patients have not been established in randomized controlled clinical trials, although the use of warfarin for the treatment or prophylaxis of thrombosis is well documented(24). Andrew et al.(25) demonstrated that 0.12 to $0.28 \mathrm{mg} / \mathrm{kg} / \mathrm{day}$ of warfarin to achieve an INR of 1.4 to 1.8 helped the dissolution of the thrombus and increased the catheter lifespan. Evidence level III; Category of recommendation $\mathrm{C}$.

\section{Thrombolysis}

Thrombus resolution is stimulated more rapidly with thrombolytics than with anticoagulants, particularly if the clot is relatively acute(26). However, the risk-benefit ratio must be carefully analyzed in each situation since bleeding risk is higher with thrombolytics than anticoagulation alone. Therefore, systemic thrombolysis in infants should be restricted to life, limb or organthreatening thrombosis, where the benefit of rapid clot resolution overweighs the risk of major hemorrhage. If the catheter is still functioning, the therapy can be directed at the thrombus through the catheter with less systemic toxicity $(12,27)$. Monagle et al (12) suggest against thrombolytic therapy for neonatal venous thromboembolism unless major vessel occlusion occurs; in these cases recombinant tissue-type plasminogen activator (rt-PA) should be used rather than other thrombolytics. The use of thrombolytic therapy in pediatrics has increased despite no established indications for thrombolysis due to the lack of well designed clinical studies(18).

\section{Streptokinase}

Streptokinase (SK) is a polypeptide produced by Group C $\beta$-hemolytic streptococci(28). Its halflife ranges from 18 to $30 \mathrm{~min}(29-31)$. Apart from bleeding, SK can cause immunogenicity leading to allergic reactions such as serum sickness-like reaction, fever, hypotension, urticaria and bronchospasm(32, 33). Therefore, SK is not considered an optimal alternative due to this risk of life-threatening anaphylaxis. In the small number of patients described in literature, doses of $1,000-2,000 \quad \mathrm{IU} / \mathrm{kg} / \mathrm{h}$ have been administered(34, 35). Evidence level III; Category of recommendation $\mathrm{C}$.

\section{Urokinase}

Urokinase (UK) is a serine protease isolated from human urine and fetal kidney cell cultures(36) and its half-life varies from 9 (administration as a bolus) to 16 minutes (administration as a continuous infusion)(37).

UK has been the drug of choice for treating thrombotic catheter occlusions restoring its patency with a single dose of $5,000 \mathrm{IU} / \mathrm{mL}$ in a volume to fill the catheter $(2 \mathrm{~mL} / \mathrm{lumen}$ in CVADs or $3 \mathrm{~mL}$ in Port-A-Caths)(18). After 2-4 $\mathrm{h}$ an attempt to infuse and withdraw samples is performed. A second attempt may be considered if the first one is unsuccessful. Evidence level $\mathrm{Ib}$; Category of recommendation A. Thrombus dissolution with local UK infusion has been effective in some patients, but not in others requiring multiple rounds of UK infusion, with rates of success ranging from 0 to $88.9 \%$ (38).

The standard regime for thrombolysis includes a bolus of $4,400 \mathrm{IU} / \mathrm{kg}$ followed by a continuous infusion of $4,400 \mathrm{IU} / \mathrm{kg} / \mathrm{h}$ during $6-12$ $\mathrm{h}(26,39)$. Longer courses have also been administered in clinical practice. However, there are numerous dosing strategies for UK used in pediatrics and doses vary if administered systemically [bolus of $7,000(4,400-50,000) \mathrm{IU} / \mathrm{kg}$ and infusion of $5,500(2,000-50,000) \mathrm{IU} / \mathrm{kg} / \mathrm{h}]$ or catheter-directed [bolus of 4,400 $(4,000-10,000)$ $\mathrm{IU} / \mathrm{kg}$ and infusion of 5,000 (2,000-120,000) $\mathrm{IU} / \mathrm{kg} / \mathrm{h}](18)$. In a more recent review a $3-\mathrm{h}$ infusion dose of $1,000 \mathrm{IU} / \mathrm{kg} / \mathrm{h}$ has also proved to be effective(40). To date insufficient evidence is available to recommend catheter-directed administration over systemic thrombolytic therapy, even if increased lytic success rates and decreased risk of bleeding complications may occur with catheter-directed administration.

UK is still available in Europe, but has been replaced in the United States by the recombinant urokinase (r-UK), which has been proved to be safe and effective in reestablishing patency of occluded CVADs in both pediatric and adult patients(41). In this multicenter study $5,000 \mathrm{UI} / \mathrm{mL}$ r-UK was administered intracatheter. Commercially available UK vials must be reconstituted with water for injection and diluted to the desired concentration with sodium chloride $0.9 \%$. This solution is stable $24 \mathrm{~h}$ at room temperature (Table 3 ).

\section{Recombinant tissue-type plasminogen activator}

Recombinant tissue-type plasminogen activator (rt-PA) or alteplase is a serine protease produced by endotelial cells(42) with a half-life of 4-5 
minutes(43). Some studies have analyzed the use of rt-PA to restore CVADs patency with doses varying from 0.5 to $2 \mathrm{mg}$ in $2 \mathrm{~mL}$ for a dwell time of 20 to 240 minutes(44-47). A second attempt can be considered if necessary(18). Evidence level III; Category of recommendation C.

Protocols for local instillation of alteplase to restore patency have been recently published(2, $12,48)$. In a double-blinded randomized trial published by Haire WD et al.(49) which included adults and children, $2 \mathrm{mg}$ of rt-PA resulted more efficient than UK in restoring catheter patency. Evidence level Ib; Category of recommendation A. Two rt-PA dosing regimens are frequently used for systemic thrombolytic therapy $(50,51)$. The high-dose regime may be used when rapid clot resolution is neccessary, i.e, in life or limbthreatening events. It consists of a continuous infusion of $0.5-0.6 \mathrm{mg} / \mathrm{kg} / \mathrm{h}$ and an assessment of the thrombus after $6 \mathrm{~h}$. A second 6-h infusion may be administered if the response is not adequate. Evidence level III; Category of recommendation C. The low-dose regimen can be administered for a longer period of time (48-96 h). The starting dose in this second option is $0.03 \mathrm{mg} / \mathrm{kg} / \mathrm{h}$, with an hourly maximum dose of $2 \mathrm{mg}(52,53)$. Evidence level IIa; Category of recommendation B. Venous thromboembolisms may respond better to this low-dose regime, as the thrombus can be lysed slowly(50, 54, 55). Increasing evidence suggests that the low-dose regime may be at least as effective as standard doses and related to fewer bleeding events $(18,55)$. As in the case of UK, reported doses of rt-PA in literature also vary if administered systemically [bolus of $0.2(0.0-0.8)$ $\mathrm{mg}$ and infusion of $0.435(0.01-3.75) \mathrm{mg}]$ or catheter-directed [bolus of $0.5(0.0-0.5) \mathrm{mg}$ and infusion of $0.08(0.015-0.2) \mathrm{mg}](18)$.

Although systemic thrombolysis with rt-PA appears to achieve a slightly higher response rate, an increased risk of bleeding complications, especially with the high-dose regime, has been observed as compared to SK or UK(18). Therefore, it is essential to use this drug with caution in patients with bleeding disorders or who are at risk of bleeding(2). Commercially available alteplase vials must be reconstituted with water for injection and diluted with sodium chloride $0.9 \%$. This solution is stable $24 \mathrm{~h}$ at room temperature, but can be stored for a longer period of time if frozen (Table 3).

\section{Reteplase}

Reteplase is a new recombinant tissue plasminogen activator similar to rt-PA but with some structural domains missing $(2,22)$. This structure results in improved thrombus penetration. Efficacy and safety of this new drug have been studied in children with cancer(56). The dose of reteplase was started at $0.1 \mathrm{IU}$ and increased incrementally by $0.1 \mathrm{IU}$ to a maximum dose of 0.4 IU. Evidence level III; Category of recommendation C. Reteplase seems to have similar efficacy as rt-PA, but requires shorter dwell times. However, prospective randomized trials are necessary to confirm this hypothesis.

\section{Surgery}

Surgical clot removal and vessel reconstruction may be indicated if life or limb threatening arterial thromboembolism or massive venous thrombosis occur(57). Evidence level IV; Category of recommendation D. With regard to the genetic predisposing factors, for neonates with clinical presentations of homozygous protein $\mathrm{C}$ deficiency, administration of fresh frozen plasma $(10-20 \mathrm{~mL} / \mathrm{kg}$ every $12 \mathrm{~h})$ or protein $\mathrm{C}$ concentrate, when available (20-60 IU/kg) are recommended until resolution of clinical lesions(12). After initial stabilization, long-term treatment with vitamin $\mathrm{K}$ antagonists, LMWH, protein $\mathrm{C}$ replacement or liver transplantation are suggested.

\section{Prophylaxis}

To decrease the incidence of catheter-related thrombosis and subsequent complications, many preventive strategies have been studied. However, clinical studies of prophylaxis for catheter-related thrombosis are inconclusive and no definitive recommendations can be made(1).

Decisions regarding the use of prophylactic anticoagulation must be based on the prothrombotic risk associated with a specific condition and the morbidity resulting from a thrombotic event(58).

\section{Normal saline flushes}

Using a normal saline flush before and after administration of bood, blood products, and medications; before and after blood sampling; and at each tubing change is recommended to minimize catheter-related occlusions(59). Evidence level IV; Category of recommendation D.

\section{Anticoagulation}

\section{Unfractionated heparin}

Most centers have protocols for routine flushing of the catheter with UFH or normal saline, but no studies have shown a difference in effectiveness between these two approaches(60-62). A recent study in pediatric oncology patients showed no difference in the incidence of catheter-related thrombosis between the two study arms: once weekly flushing with saline solution via a 
positive-pressure cap and twice-weekly flushing with $200 \mathrm{IU} / \mathrm{mL}$ UFH via a standard cap(63).

However, more catheter-occlusions and catheterinfections occured in the normal saline arm. Evidence level Ib; Category of recommendation A. The use of $100 \mathrm{UI} / \mathrm{mL}$ heparin flush is not recommended for use in neonates(24). With regard to heparin-bonded catheters, in a study with 50 children in an intensive care unit, which compared a heparin-bonded vs a standard femoral venous catheter, the first approach was far more effective(64). These results were consistent with a study pubished by Pierce CM et al.(65), but not with the randomized controlled trial carried out by Anton $\mathrm{N}$ et al.(66). The use of heparin-bonded catheters in children for prolonging patency seems promising, but further studies are warranted(67). Evidence level Ia; Category of recommendation $\mathrm{A}$.

In a meta-analysis mainly based on adults and conducted by Randolf et al.(68) to assess the benefit of heparin in central venous and pulmonary artery catheters, systemically and catheter-bonded heparin was beneficial in preventing catheter occlusion. Evidence level Ia; Category of recommendation A. In neonates, Shah PS et al.(69) proved that a heparin infusion at $0.5 \mathrm{IU} / \mathrm{kg} / \mathrm{h}$ prolonged the duration of peripherally inserted central venous catheter usability compared to placebo. Evidence level Ib; Category of recommendation A. On the other hand, in the recent work carried out by Schroeder AR et al.(70) a continuous infusion of heparin at $10 \mathrm{IU} / \mathrm{kg} / \mathrm{h}$ was safe but did not succeed in reducing catheter-related thrombus formation in infants. Evidence level Ib; Category of recommendation $\mathrm{A}$.

The addition of $1 \mathrm{IU} / \mathrm{mL}$ heparin to the parenteral nutrition (PN) solution is controversial, since there are studies with a high evidence level, but with contradictory results. A randomized controlled trial demonstrated no benefit in preventing thrombosis(71). However, a recent study published by Uslu S et al.(72) concluded that in neonatos with CVADs, low-dose continuous infusion of $0.5 \mathrm{IU} / \mathrm{kg} / \mathrm{h}$ within the PN is an effective measure to reduce catheter oclusion. Evidence level Ib; Category of recommendation A. A disadvantage of heparin is potential appearance of heparin induced thrombocytopenia and loss of bone mineral.

\section{Low molecular weight heparin}

In pediatric oncology patients, Mitchell et al.(73) concluded that LMWH (1 $\mathrm{mg} / \mathrm{kg} / 24 \quad \mathrm{~h}$ enoxaparin) may help to prevent catheter-related thrombosis in high-risk patients. Evidence level IIa; Category of recommendation B. Monagle et al.(12) recommend prophylactic doses of enoxaparin of $0.75 \mathrm{mg} / \mathrm{kg} / 12 \mathrm{~h}$ in children less than 2 months old and $0.5 \mathrm{mg} / \mathrm{kg} / 12 \mathrm{~h}$ in children older than 2 months. However, they warn against the use of routine systemic thromboprophylaxis for children with CVADs. Evidence level Ib; Category of recommendation $\mathrm{B}$.

\section{Oral anticoagulants}

Very low doses of warfarin (1 mg daily beginning 3 days before catheter insertion and continuing for 90 days) have been shown to be effective in reducing catheter-related thrombosis in adult patients(74). Evidence level Ib; Category of recommendation $\mathrm{A}$.

In a study with children on home $\mathrm{PN}$, warfarin increased the patency of the catheter from 161 to 351 days and no new thrombosis and major bleeding episodes occured(75). Evidence level III; Category of recommendation C. The main drawback of this work was the small sample size, only 8 patients. The pharmacokinetics of chemotherapeutic agents, antibiotics and other medications may be greatly affected by the administration of warfarin(76-78). Recent studies of low-dose warfarin do not support its use in prophylaxis of catheter occlusions(79). Evidence level III; Category of recommendation C. Prophylactic flushes with heparin or saline are the standard of care to mantain the patency of CVADs(2). New oral anticoagulants, such as direct factor Xa or thrombin inhibitors, which can be given in fixed doses with little monitoring in comparison with the conventional oral anticoagulants, may be promising.

\section{Thrombolysis}

Children receiving intraluminal application of UK $(10,000 \mathrm{IU}$ in each catheter lumen for $4 \mathrm{~h})$ once a week showed a decreased rate of catheter occlusion compared to children without prophylaxis, and no hemorrhagic complications were observed(80). Evidence level IIa; Category of recommendation $B$. In the prospective study published by Dillon PW et al.(81) 5,000 IU/mL of UK every two weeks significantly decreased the rates of occlusive events compared to $100 \mathrm{IU} / \mathrm{mL}$ of heparin. Evidence level Ib; Category of recommendation $\mathrm{A}$.

With regard to rt-PA, in a randomized controlled trial comparing alteplase vs heparin for maintaining the patency of paediatric central venous haemodialysis lines(82), $1 \mathrm{mg} / \mathrm{mL}$ of alteplase was significantly more effective than $5,000 \mathrm{IU} / \mathrm{mL}$ of heparin in preventing clot formation. Evidence level Ib; Category of recommendation $\mathrm{A}$. 
Other strategies

Jacobs BR et al.(83) failed to demonstrate that a nitroglicerin infusion reduced the incidence of catheter-related thrombosis in children. Evidence level Ib; Category of recommendation A.

\section{DISCUSSION}

Catheter thrombotic occlusions and catheterrelated thrombosis in pediatric patients have become increasingly prevalent in the last years. However, present data are inconclusive and further research is necessary for more clearly defined guidelines and recommendations as regards both treatment and prophylaxis of catheter-related thromboembolism in pediatric patients. Due to the wide variety of options available for the pharmacotherapeutic management and until more evidence on the comparative efficacy and safety of the different drugs is found, therapeutic positioning is based on the authorized indications, commercial availability of the different agents, clinical experience, associated costs and patient specific characteristics, i.e., age or bleeding risk. Randomized controlled trials and national plans should be set up urgently.

\section{ACKNOWLEDGEMENTS}

The authors would like to thank Braden Lang for editorial assistance. The authors have indicated that they have no conflicts of interest regarding the content of this article.

\section{REFERENCES}

1. Revel-Vilk S. Central venous line-related thrombosis in children. Acta Haematol. 2006;115(3-4):201-6.

2. Kerner JA, Jr., Garcia-Careaga MG, Fisher AA, Poole RL. Treatment of catheter occlusion in pediatric patients. JPEN J Parenter Enteral Nutr. 2006 Jan-Feb;30(1 Suppl):S73-81.

3. Stephens LC, Haire WD, Kotulak GD. Are clinical signs accurate indicators of the cause of central venous catheter occlusion? JPEN J Parenter Enteral Nutr. 1995 Jan-Feb;19(1):75-9.

4. Freytes CO. Thromboembolic complications related to indwelling central venous catheters in children. Curr Opin Oncol. 2003 Jul;15(4):289-92.

5. Gorski LA. Central venous access device occlusions: part 1: thrombotic causes and treatment. Home Healthc Nurse. 2003 Feb;21(2):115-21; quiz 22.

6. Timsit JF, Farkas JC, Boyer JM, Martin JB, Misset B, Renaud B, et al. Central vein catheterrelated thrombosis in intensive care patients: incidence, risks factors, and relationship with catheter-related sepsis. Chest. 1998 Jul;114(1):207-13.

7. Richardson MW, Allen GA, Monahan PE. Thrombosis in children: current perspective and distinct challenges. Thromb Haemost. 2002 Dec;88(6):900-11.

8. Miller K, Buchanan GR, Zappa S, Cochran C, Laufenberg $\mathrm{J}$, Medeiros $\mathrm{D}$, et al. Implantable venous access devices in children with hemophilia: a report of low infection rates. J Pediatr. 1998 Jun;132(6):934-8.

9. Barnes C, Newall F, Monagle P. Post-thrombotic syndrome. Arch Dis Child. 2002 Mar;86(3):212-4.

10. Hausler M, Hubner D, Delhaas T, Muhler EG. Long term complications of inferior vena cava thrombosis. Arch Dis Child. 2001 Sep;85(3):22833.

11. Wilimas JA, Hudson M, Rao B, Luo X, Lott L, Kaste SC. Late vascular occlusion of central lines in pediatric malignancies. Pediatrics. 1998 Feb;101(2):E7.

12. Monagle $\mathrm{P}$, Chan AK, Goldenberg NA, Ichord $\mathrm{RN}$, Journeycake JM, Nowak-Gottl U, et al. Antithrombotic therapy in neonates and children: Antithrombotic Therapy and Prevention of Thrombosis, 9th ed: American College of Chest Physicians Evidence-Based Clinical Practice Guidelines. Chest. Feb;141(2 Suppl):e737S-801S.

13. Deerojanawong J, Sawyer SM, Fink AM, Stokes $\mathrm{KB}$, Robertson CF. Totally implantable venous access devices in children with cystic fibrosis: incidence and type of complications. Thorax. 1998 Apr;53(4):285-9.

14. Jeng MR, Feusner J, Skibola C, Vichinsky E. Central venous catheter complications in sickle cell disease. Am J Hematol. 2002 Feb;69(2):1038.

15. Fratino G, Molinari AC, Mazzola C, Giacchino M, Saracco P, Bertocchi E, et al. Prospective study of indwelling central venous catheter-related complications in children with broviac or clampless valved catheters. J Pediatr Hematol Oncol. 2002 Nov;24(8):657-61.

16. Ingram J, Weitzman S, Greenberg ML, Parkin P, Filler R. Complications of indwelling venous access lines in the pediatric hematology patient: a prospective comparison of external venous catheters and subcutaneous ports. Am J Pediatr Hematol Oncol. 1991 Summer;13(2):130-6.

17. Journeycake JM, Buchanan GR. Thrombotic complications of central venous catheters in children. Curr Opin Hematol. 2003 Sep;10(5):36974.

18. Albisetti M. Thrombolytic therapy in children. Thromb Res. 2006;118(1):95-105.

19. Albisetti M. The fibrinolytic system in children. Semin Thromb Hemost. 2003 Aug;29(4):339-48.

20. Andrew M, David M, Adams M, Ali K, Anderson $\mathrm{R}$, Barnard D, et al. Venous thromboembolic complications (VTE) in children: first analyses of the Canadian Registry of VTE. Blood. 1994 Mar 1;83(5):1251-7. 
21. Schmidt B, Andrew M. Neonatal thrombosis: report of a prospective Canadian and international registry. Pediatrics. 1995 Nov;96(5 Pt 1):939-43.

22. van Ommen $\mathrm{CH}$, Tabbers $\mathrm{MM}$. Catheter-related thrombosis in children with intestinal failure and long-term parenteral nutrition: how to treat and to prevent? Thromb Res. Dec;126(6):465-70.

23. Andrew M, Michelson AD, Bovill E, Leaker M, Massicotte MP. Guidelines for antithrombotic therapy in pediatric patients. J Pediatr. 1998 Apr;132(4):575-88.

24. Thomson healthcare products: select a product [Internet]. Thomson Reuters Healthcare [cited October 17, 2011]. Available from: http://www.thomsonhc.com/home/dispatch

25. Andrew M, Marzinotto V, Pencharz P, Zlotkin S, Burrows $\mathrm{P}$, Ingram J, et al. A cross-sectional study of catheter-related thrombosis in children receiving total parenteral nutrition at home. J Pediatr. 1995 Mar;126(3):358-63.

26. Raffini L. Thrombolysis for intravascular thrombosis in neonates and children. Curr Opin Pediatr. 2009 Feb;21(1):9-14.

27. Savage SA, Young G, Reaman GH. Catheterdirected thrombolysis in a child with acute lymphoblastic leukemia and extensive deep vein thrombosis. Med Pediatr Oncol. 2000 Mar;34(3):215-7.

28. Jackson KW, Tang J. Complete amino acid sequence of streptokinase and its homology with serine proteases. Biochemistry. 1982 Dec 21;21(26):6620-5.

29. Mentzer RL, Budzynski AZ, Sherry S. High-dose, brief-duration intravenous infusion of streptokinase in acute myocardial infarction: description of effects in the circulation. Am J Cardiol. 1986 Jun 1;57(15):1220-6.

30. Col JJ, Col-De Beys CM, Renkin JP, LavennePardonge EM, Bachy JL, Moriau MH. Pharmacokinetics, thrombolytic efficacy and hemorrhagic risk of different streptokinase regimens in heparin-treated acute myocardial infarction. Am J Cardiol. 1989 May 15;63(17):1185-92.

31. Agencia Española de Medicamentos y Productos Sanitarios. Streptokinase Product Information. http://www.aemps.gob.es/cima/especialidad.do?m etodo $=$ verFichaWordPdf $\&$ codigo $=49787 \&$ format $\mathrm{o}=$ pdf\&formulario=FICHAS\&file=ficha.pdf. Accessed January 15, 2012.

32. Lee HS, Yule S, McKenzie A, Cross S, Reid T, Davidson $\mathrm{R}$, et al. Hypersensitivity reactions to streptokinase in patients with high pre-treatment antistreptokinase antibody and neutralisation titres. Eur Heart J. 1993 Dec;14(12):1640-3.

33. Long-term effects of intravenous thrombolysis in acute myocardial infarction: final report of the GISSI study. Gruppo Italiano per lo Studio della Streptochi-nasi nell'Infarto Miocardico (GISSI). Lancet. 1987 Oct 17;2(8564):871-4.

34. Hausler M, Hubner D, Hornchen H, Muhler EG, Merz U. Successful thrombolysis of inferior vena cava thrombolysis in a preterm neonate. Clin Pediatr (Phila). 2001 Feb;40(2):105-8.

35. Nowak-Gottl U, von Kries R, Gobel U. Neonatal symptomatic thromboembolism in Germany: two year survey. Arch Dis Child Fetal Neonatal Ed. 1997 May;76(3):F163-7.

36. Wun TC, Ossowski L, Reich E. A proenzyme form of human urokinase. J Biol Chem. 1982 Jun 25;257(12):7262-8.

37. Agencia Española de Medicamentos y Productos Sanitarios. Urokinase Product Information. http://www.aemps.gob.es/cima/especialidad.do?m etodo $=$ verFichaWordPdf\&codigo $=55422 \&$ format $\mathrm{o}=$ pdf\&formulario $=$ FICHAS $\&$ file $=$ ficha.pdf. Accessed January 15, 2012.

38. Kakzanov V, Monagle P, Chan AK. Thromboembolism in infants and children with gastrointestinal failure receiving long-term parenteral nutrition. JPEN J Parenter Enteral Nutr. 2008 Jan-Feb;32(1):88-93.

39. Alkalay AL, Mazkereth R, Santulli T, Jr., Pomerance JJ. Central venous line thrombosis in premature infants: a case management and literature review. Am J Perinatol. 1993 Jul;10(4):323-6.

40. Simon A, Bode U, Lieber K, Beutel K, Fleischhack G. Review and update of the use of urokinase in the prevention and management of CVAD-related complications in pediatric oncology patients. Am J Infect Control. 2008 Feb;36(1):54-8.

41. Svoboda P, Barton RP, Barbarash OL, Butylin AA, Jacobs BR, Lata J, et al. Recombinant urokinase is safe and effective in restoring patency to occluded central venous access devices: a multiple-center, international trial. Crit Care Med. 2004 Oct;32(10):1990-6.

42. Pennica D, Holmes WE, Kohr WJ, Harkins RN, Vehar GA, Ward CA, et al. Cloning and expression of human tissue-type plasminogen activator cDNA in E. coli. Nature. 1983 Jan 20;301(5897):214-21.

43. Agencia Española de Medicamentos y Productos Sanitarios. Alteplase Product Information. http://www.aemps.gob.es/cima/especialidad.do?m etodo $=$ verFichaWordPdf\&codigo $=59494 \&$ format $\mathrm{o}=$ pdf\&formulario $=$ FICHAS\& file $=$ ficha.pdf. Accessed January 15, 2012.

44. Chesler L, Feusner JH. Use of tissue plasminogen activator (rt-PA) in young children with cancer and dysfunctional central venous catheters. J Pediatr Hematol Oncol. 2002 Nov;24(8):653-6.

45. Jacobs BR, Haygood M, Hingl J. Recombinant tissue plasminogen activator in the treatment of central venous catheter occlusion in children. J Pediatr. 2001 Oct;139(4):593-6.

46. Choi M, Massicotte MP, Marzinotto V, Chan AK, Holmes JL, Andrew M. The use of alteplase to restore patency of central venous lines in pediatric patients: a cohort study. J Pediatr. 2001 Jul;139(1):152-6. 
47. Kleta R, Schleef J, Jurgens H. Tissue plasminogen activator and obstructed central venous catheters. Med Pediatr Oncol. 1998 Jun;30(6):376.

48. Hartmann J, Hussein A, Trowitzsch E, Becker J, Hennecke KH. Treatment of neonatal thrombus formation with recombinant tissue plasminogen activator: six years experience and review of the literature. Arch Dis Child Fetal Neonatal Ed. 2001 Jul;85(1):F18-22.

49. Haire WD, Atkinson JB, Stephens LC, Kotulak GD. Urokinase versus recombinant tissue plasminogen activator in thrombosed central venous catheters: a double-blinded, randomized trial. Thromb Haemost. 1994 Oct;72(4):543-7.

50. Wang M, Hays T, Balasa V, Bagatell R, Gruppo $\mathrm{R}$, Grabowski EF, et al. Low-dose tissue plasminogen activator thrombolysis in children. J Pediatr Hematol Oncol. 2003 May;25(5):379-86.

51. Gupta AA, Leaker M, Andrew M, Massicotte P, Liu L, Benson LN, et al. Safety and outcomes of thrombolysis with tissue plasminogen activator for treatment of intravascular thrombosis in children. J Pediatr. 2001 Nov;139(5):682-8.

52. Goldenberg NA, Durham JD, Knapp-Clevenger R, Manco-Johnson MJ. A thrombolytic regimen for high-risk deep venous thrombosis may substantially reduce the risk of postthrombotic syndrome in children. Blood. 2007 Jul 1;110(1):45-53.

53. Manco-Johnson MJ. How I treat venous thrombosis in children. Blood. 2006 Jan $1 ; 107(1): 21-9$.

54. Newall F, Browne M, Savoia H, Campbell J, Barnes C, Monagle P. Assessing the outcome of systemic tissue plasminogen activator for the management of venous and arterial thrombosis in pediatrics. J Pediatr Hematol Oncol. 2007 Apr;29(4):269-73.

55. Fasano R, Kent P, Valentino L. Superior vena cava thrombus treated with low-dose, peripherally administered recombinant tissue plasminogen activator in a child: case report and review of the literature. J Pediatr Hematol Oncol. 2005 Dec;27(12):692-5.

56. Terrill KR, Lemons RS, Goldsby RE. Safety, dose, and timing of reteplase in treating occluded central venous catheters in children with cancer. J Pediatr Hematol Oncol. 2003 Nov;25(11):864-7.

57. Veldman A, Nold MF, Michel-Behnke I. Thrombosis in the critically ill neonate: incidence, diagnosis, and management. Vasc Health Risk Manag. 2008;4(6):1337-48.

58. Donnelly KM. Venous thromboembolic disease in the pediatric intensive care unit. Curr Opin Pediatr. 1999 Jun;11(3):213-7.

59. Harris JL, Maguire D. Developing a protocol to prevent and treat pediatric central venous catheter occlusions. J Intraven Nurs. 1999 JulAug;22(4):194-8.

60. Smith S, Dawson S, Hennessey R, Andrew M. Maintenance of the patency of indwelling central venous catheters: is heparin necessary? Am J
Pediatr Hematol Oncol. 1991 Summer;13(2):1413.

61. Stephens LC, Haire WD, Tarantolo S, Reed E, Schmit-Pokorny K, Kessinger A, et al. Normal saline versus heparin flush for maintaining central venous catheter patency during apheresis collection of peripheral blood stem cells (PBSC). Transfus Sci. 1997 Jun;18(2):187-93.

62. LeDuc K. Efficacy of normal saline solution versus heparin solution for maintaining patency of peripheral intravenous catheters in children. $\mathrm{J}$ Emerg Nurs. 1997 Aug;23(4):306-9.

63. Cesaro S, Tridello G, Cavaliere M, Magagna L, Gavin P, Cusinato R, et al. Prospective, randomized trial of two different modalities of flushing central venous catheters in pediatric patients with cancer. J Clin Oncol. 2009 Apr 20;27(12):2059-65.

64. Krafte-Jacobs B, Sivit CJ, Mejia R, Pollack MM. Catheter-related thrombosis in critically ill children: comparison of catheters with and without heparin bonding. J Pediatr. 1995 Jan;126(1):50-4.

65. Pierce CM, Wade A, Mok Q. Heparin-bonded central venous lines reduce thrombotic and infective complications in critically ill children. Intensive Care Med. 2000 Jul;26(7):967-72.

66. Anton N, Cox PN, Massicotte MP, Chait P, Yasui Y, Dinyari PM, et al. Heparin-bonded central venous catheters do not reduce thrombosis in infants with congenital heart disease: a blinded randomized, controlled trial. Pediatrics. 2009 Mar;123(3):e453-8.

67. Shah PS, Shah N. Heparin-bonded catheters for prolonging the patency of central venous catheters in children. Cochrane Database Syst Rev. 2007(4):CD005983.

68. Randolph AG, Cook DJ, Gonzales CA, Andrew M. Benefit of heparin in central venous and pulmonary artery catheters: a meta-analysis of randomized controlled trials. Chest. 1998 Jan;113(1):165-71.

69. Shah PS, Kalyn A, Satodia P, Dunn MS, Parvez B, Daneman A, et al. A randomized, controlled trial of heparin versus placebo infusion to prolong the usability of peripherally placed percutaneous central venous catheters (PCVCs) in neonates: the HIP (Heparin Infusion for PCVC) study. Pediatrics. 2007 Jan;119(1):e284-91.

70. Schroeder AR, Axelrod DM, Silverman NH, Rubesova E, Merkel E, Roth SJ. A continuous heparin infusion does not prevent catheter-related thrombosis in infants after cardiac surgery. Pediatr Crit Care Med. Jul;11(4):489-95.

71. Kamala F, Boo NY, Cheah FC, Birinder K. Randomized controlled trial of heparin for prevention of blockage of peripherally inserted central catheters in neonates. Acta Paediatr. 2002;91(12):1350-6.

72. Uslu S, Ozdemir H, Comert S, Bolat F, Nuhoglu A. The effect of low-dose heparin on maintaining peripherally inserted percutaneous central venous catheters in neonates. J Perinatol. Dec;30(12):794-9. 
73. Mitchell L, Lambers M, Flege S, Kenet G, LiThiao-Te V, Holzhauer S, et al. Validation of a predictive model for identifying an increased risk for thromboembolism in children with acute lymphoblastic leukemia: results of a multicenter cohort study. Blood. Jun 17;115(24):4999-5004.

74. Bern MM, Lokich JJ, Wallach SR, Bothe A, Jr., Benotti PN, Arkin CF, et al. Very low doses of warfarin can prevent thrombosis in central venous catheters. A randomized prospective trial. Ann Intern Med. 1990 Mar 15;112(6):423-8.

75. Newall F, Barnes C, Savoia H, Campbell J, Monagle P. Warfarin therapy in children who require long-term total parenteral nutrition. Pediatrics. 2003 Nov;112(5):e386.

76. Streif W, Andrew M, Marzinotto V, Massicotte P, Chan AK, Julian JA, et al. Analysis of warfarin therapy in pediatric patients: A prospective cohort study of 319 patients. Blood. 1999 Nov 1;94(9):3007-14.

77. Massicotte P, Leaker M, Marzinotto V, Adams M, Freedom R, Williams W, et al. Enhanced thrombin regulation during warfarin therapy in children compared to adults. Thromb Haemost. 1998 Oct;80(4):570-4.

78. Masci G, Magagnoli M, Zucali PA, Castagna L, Carnaghi C, Sarina B, et al. Minidose warfarin prophylaxis for catheter-associated thrombosis in cancer patients: can it be safely associated with fluorouracil-based chemotherapy? J Clin Oncol. 2003 Feb 15;21(4):736-9.

79. Kuter DJ. Thrombotic complications of central venous catheters in cancer patients. Oncologist. 2004;9(2):207-16.

80. Kalmanti M, Germanakis J, Stiakaki E, Syfridaki C, Christidou A, Tsetis D, et al. Prophylaxis with urokinase in pediatric oncology patients with central venous catheters. Pediatr Hematol Oncol. 2002 Apr-May;19(3):173-9.
81. Dillon PW, Jones GR, Bagnall-Reeb HA, Buckley JD, Wiener ES, Haase GM. Prophylactic urokinase in the management of long-term venous access devices in children: a Children's Oncology Group study. J Clin Oncol. 2004 Jul 1;22(13):2718-23.

82. Gittins NS, Hunter-Blair YL, Matthews JN, Coulthard MG. Comparison of alteplase and heparin in maintaining the patency of paediatric central venous haemodialysis lines: a randomised controlled trial. Arch Dis Child. 2007 Jun;92(6):499-501.

83. Jacobs BR, Barr LL, Brilli RJ, Lyons KA, Wong HR. Intracatheter nitroglycerin infusion fails to prevent catheter-related venous thrombosis: a randomized, controlled trial. Intensive Care Med. 2001 Jan;27(1):187-92.

84. Harris RP, Helfand M, Woolf SH, Lohr KN, Mulrow CD, Teutsch SM, et al. Current methods of the US Preventive Services Task Force: a review of the process. Am J Prev Med. 2001 Apr;20(3 Suppl):21-35.

85. Agencia Española de Medicamentos y Productos Sanitarios. Heparin Product Information. http:/www.aemps.gob.es/cima/especialidad.do?m etodo $=$ verFichaWordPdf\&codigo $=50156 \&$ format $\mathrm{o}=$ pdf $\&$ formulario $=$ FICHAS $\&$ file $=$ ficha.pdf. Accessed January 15, 2012.

86. Davis SN, Vermeulen L, Banton J, Schwartz BS, Williams EC. Activity and dosage of alteplase dilution for clearing occlusions of venous-access devices. Am J Health Syst Pharm. 2000 Jun 1;57(11):1039-45.

87. Trissel LA, ed. Handbook on Injectable Drugs. 15th ed. Bethesda, MD: American Society of Health-System Pharmacists; 2009. 